\title{
PELATIHAN KERAJINAN TEMPURUNG KELAPA DI DESA TIANYAR
}

\author{
Desak Putu Parmiti, I Wayan Widiana, I Nyoman Aracana \\ Universitas Pendidikan Ganesha
}

\begin{abstract}
ABSTRAK
Tujuan umum dari pengabdian ini adalah untuk memberikan peluang usaha baru bagi kelompok Sri Amerta Sari dan Karya Santhi di desa Tianyar dengan memberikan pelatihan kerajinan tempurung kelapa dan manajemen dan administrasinya serta dilengkapi engan SIUP. Pengabdian ini dilaksanakan selama 4 Bulan yaitu mulai tanggal 1 Juni sampai dengan 30 September 2015 di Desa Tianyar Kecamatan Kubu kabupaten Karangasem. Metode yang digunakan dalam pelatihan ini adalah metode diklat dan praktek langsung yang dimulai dari perencanaan, pelaksanaan dan evaluasi. Jumlah peserta yang ikut adalah 30 orang yang berasala dari kelompok Sri Amerta Sari dan Kelompok Karya Santhi. Ketentuannya dari 30 peserta pelatihan yang mengikuti program ini, pelatihan dianggap berhasil jika $95 \%$ peserta dapat menyelesaikan seluruh program pelatihan. Namun harapan penyelenggara, seluruh peserta pelatihan $(100 \%)$ agar dapat menyelesaikan program ini. Dan pembelajar dianggap berhasil bila sudah menyerap $80 \%$ materi dalam penyelesaian tugas-tugas belajar dan mampu memanfaatkan pengetahuan yang diperoleh untuk meningkatkan kualitas keterampilan kerajinan tempurung kelapa yang pada akhirnya akan dapat meningkatkan kehidupan perekonomian mereka. Hasil yang dicapai dalam pengabdian ini adalah (1) tingkat partisipasi yang tinggi dari mitra program pengabdian kepada masyarakat memberikan dampak positif bagi pelaksanaan program, terlihat dari kehadiran peserta yang tanpa ijin, dan dukungan dari kepala desa, (2) Hasil pelatihan menunjukkan bahwa dari 30 orang yang ikut pelatihan 25 orang $(83,33 \%)$ masuk dalam kategori sangat mengetahui dan terampil dalam pembuatan kerajinan tempurung kelapa, 2 orang $(2,66)$ termasuk dalam kategori kategori mengetahui dan terampil dalam pembuatan kerajinan tempurung kelapa, dan 5 orang $(16,66)$ termasuk dalam kategori cukup mengetahui dan terampil pembuatan kerajinan tempurung kelapa, (3) Hasil pelatihan menunjukkan bahwa dari 30 orang yang ikut pelatihan 20 orang $(66,67 \%)$ masuk dalam kategori sangat mengetahui dan terampil dalam mengkreasikan kerajinan tempurung kelapa, $5(16,66)$ orang termasuk dalam kategori kategori mengetahui dan terampil dalam mengkreasikan kerajinan tempurung kelapa, dan 5 orang $(16,66)$ termasuk dalam kategori cukup mengetahui dan terampil dalam kerajinan tempurung kelapa, dan (4) Kendala pelaksanaan program adalah sulitnya meminid waktu untuk pencapaian kesepakatan pelaksanaan kegiatan, karena umumnya peserta latihan terbentur dengan rutinitas pekerjaan harian yang menunjang perekonomian keluarga, maupun pelaksanaan kegiatan ritual adat-istiadat yang lumayan padat di banjar tunassari desa Tianyar dalam kaitannya dengan paruman desa adat untuk penyelenggaraan ritual keagamaan sebagaimana layaknya masyarakat Hindu Bali pada umumnya.
\end{abstract}

Kata Kunci: Tempurung Kelapa

\section{PENDAHULUAN}

Pemberdayaan masyarakat merupakan upaya untuk mengubah dan membentuk kehidupan masyarakat. Pemberdayaan akan meningkatkan kemampuan anggota masyarakatnya agar dapat mengarahkan, mengendalikan, membentuk dan mengelola hidupnya. Pemberdayaan masyarakat juga akan meningkatkan kemampuan seseorang untuk dapat mengelola hidupnya secara mandiri sebagai indikator pemberdayaan meliputi kemampuan: i) Memahami masalah, ii) Menilai tujuan hidupnya,iii) Membentuk strategi, iii) Mengelola sumber daya, iv) Bertindak dan berbuat.
Selanjutnya pembangunan masyarakat merupakan suatu proses yang berkelanjutan dengan pendekatan holistik atau menyeluruh sesuai dengan kebutuhan masyarakat, kemudian menerapkan pemberdayaan yang berpengaruh, melibatkan, dan mendidik; menjamin keseimbangan lingkungan; memastikan keberlanjutan/kebertahanan, dan menggunakan kemitraan untuk membuka akses untuk sumber daya dan dana.

Kecamatan Kubu kabupaten Karangasem memiliki masyarakat buta huruf yang sangat besar. Berdasarkan data yang tercatat di kantor kecataman 
kubu $60 \%$ dari penduduk produktif (umur 20 tahun ketas) buta aksara. Kehidupan ini sangat mngganggu kehidupan sosial masyarakat secara menyeluruh. Secara umum masyarakat desa sangat cerdas dan kaya keterampilan yang perlu dikembangkan. Namun, sayang sekali, selama ini keaksaraan usaha mandiri hanya dipandang sebelah mata oleh masyarakat desa. Kondisi ini menyebabkan tingkat perkembangan masyarakat menjadi sangat rendah. Ini tentu saja menyebabkan pendapatan yang juga rendah di kalangan masyarakat.

Desa Tianyar sebenarnya memiliki potensi yang besar yang bisa dikembangkan dalam bidang kerajinan karena desa Tianyar memiliki bahan baku tempurung kelapa yang sangat melimpah. Desa Tianyar berjarak $30 \mathrm{~km}$ dari kota Amlapura-Kabupaten Karangasem-Bali, merupakan daerah kering yang banyak ditumbuhi tanaman kelapa yang sering dicari janurnya digunakan sebagai sarana upacara, buahnya dijual dan kadangkadang dijadikan minyak. Buah kepala yang dijual adalah isinya, tempurungnya biasanya hanya digunakan sebagai arang atau bahkan dibuang begitu saja. Sampai saat ini desa Tianyar hanya mampu bergerak aktif dalam penghasil bahan baku dari tanaman Kelapa bukan akif sebagai pengolah bahan baku tanaman Kelapa. Padahal di Desa Tianyar jumlah penduduk miskin dan dan Buta Aksara cukup tinggi. Data dari BPS tahun 2010 menunjukkan bahwa desa Tianyar memiliki penduduk yang buta aksara 845 orang dari 1717 penduduk yang tercatat.

Sebenarnya, di Desa Tianyar ada beberapa kumpulan keluarga dan kelompok tani yang dibentuk dengan tujuan membentuk usaha tani, yakni kelompok Sri Amerta Sari dan kelompok Karya Santhi. Kelompok ini sudah lama dibentuk oleh masyarakat, namun dari sejak berdirinya tahun 1995 sampai sekarang (2014) perkembangannya bisa dikatakan stagnan. Hal ini dapat dilihat dari produk pertani (buah-buahan, kelapa, kacang-kacangan, dan lontar) yang dihasilkan masih minim nilai jual. Sampai saat ini hasil produksinya tidak mampu bersaing di pasaran, bahkan di pasaran domestik saja masih belum berkategori layak jual. Hal ini disebabkan oleh beberapa faktor, diantaranya kemampuan seni dan jiwa wirausaha masyarakat masih rendah, sehingga hasil produksinya tidak memiliki nilai jual yang tinggi. Dampaknya, pertanian, usaha dan usaha kerajinan tempurung Kelapa ini belum mampu mendongkrak perekonomian komunitas masyarakat desa Tianyar secara signifikan. Sampai saat ini belum banyak upaya-upaya yang dilakukan masyarakat Tianyar untuk memperbaiki kualitas dan kuantitas produksi. Desa Tianyar sebagai lumbung Kelapa yang menjadi penciri keunikan masyarakat melalui intensifikasi dan ekstensifikasi produk kerajinan seni, sehingga potensi desa tidak dapat berkebang dengan baik.

Kerajinan tempurung kelapa merupakan salah satu hasil kerajinan yang mimiliki nilai seni tinggi. Kerajinan tempurung kelapa bisa digunakan sebagai tempat minum, tempat makan, model main-mainan. Bali sebagai daerah pariwisata tidak sulit untuk memasarkan kerajinan tempurung kelapa di Bali. Barang seperti ini bias dipasarkan di hotel, restoran atau bahkan di tempat pernak pernik Bali atau souvernir bali. Proses pembuatan kerajinan tempurung kelapa dari tempurung Kelapa tidak begitu sulit, berdasarkan hasil percobaan sementara, warga yang diberikan contoh untuk belajar membuat kerajinan tempurung kelapa hanya memebutuhkan waktu 4 hari yaitu belajar 1 hari tehnik dasar, 2 hari kreasi dan 1 hari finishing.

Proses pembuatan kerajinan tempurung kelapa di atas masih bersifat tradisional dan manual, sehingga kualitas kerajinan tempurung Kelapa yang dihasilkan tidak dapat terjaga dengan baik. agar menghasilkan karya yang lebih baik diperlukan semacam perabotan dan bahan yang digunakan untuk membuat dan mengawetkan serta mengemas barang agar lebih menarik. Minimnya teknologi yang dimiliki dan diketahui oleh masyarakat sering menghambat ketercapaian target produksi dari kesepakatan waktu yang telah disepakati dengan kostumer. Sehingga terbatasnya teknologi yang digunakan seperti berbagai macam pemotong dan penghalus yang digunakan dalam membuat kerajinan 
tempurung kelapa, akan menimbulkan komplain dari costumer/suplier. Oleh sebab itu perlu diberikan pelatihan untuk membuat teknologi pemotong dan penghalus dari bahan yang ada disekitarnya.

Dari sisi desain dan pewarnaan, agar produk seni kerajinan tempurung Kelapa yang dihasilkan tidak tampak monoton, perlu dilakukan pelatihan desain dan pewarnaan seperti pemberian sentuhan warna tempurung kelapa baik yang diberikan secara manual-artifisial melalui lukisan tangan maupun melalui proses kimia dengan peleburan dan pengawetan. Sehingga hasil an dan kerajinan mampu menangkap selera konsumen untuk trend produk yang diminati costumer, nilai jual produk kerajinan kerajinan tempurung Kelapa pun dapat ditingkatkan.

Agar pemasaran produksi kerajinan tempurung kelapa tidak terbatas pada pemasaran lokal. Daya jual produksi sebagai karya seni harus diminati oleh pasar berskala regional, nasional maupun mancanegara. Dengan menjangkau pasar yang luas masyarakata akan mendapat keuntungan lebih banyak dari hasil produksinya. Dari hasil perhitungan sementara bersama warga terhadap catatan cash-flow keuangan kedua kelompok ini dari hasil pertanian, menunjukkan bahwa rata-rata omzet penjualan produksi pertanian kelompok Karya Santhi dan kelompok Sri Amerta Sari sebesar Rp.350.000-1.600.000/bulan. Biaya produksi yang diperlukan rata-rata Rp.50-400 ribu/bulan, sehingga netto keuntungan kotor yang diperoleh hanya Rp.300.000 - 1.200 .000 /bulan. Jumlah anggota masing-masing kelompok yang bekerja pada setiap usaha kelompok tersebut sebanyak 20 orang, maka penghasilan buruh setiap bulan rata-rata 200 ribu /bulan. Penghasilan ini relatif kecil bila dibandingkan dengan penghasilan yang diperoleh pengrajin bambu atau kerajinan yang lain, yang bisa mencapai 1,5-3 juta/bulan. Untuk meningkat generate revenue dan keuntungan dari kelompok tersebut tampaknya peningkatan pelatihan tentang kualitas produksi dan pemasaran diperlukan untuksabagai salah satu alternatif pemecahannya.

Tujuan dari kegiatan ini adalah untuk (1) memberikan peluang usaha baru bagi kelompok Sri Amerta Sari dan Karya Santhi di desa Tianyar, (2) meningkatkan pengetahuan dan pemahaman tentang sistem pembukuan (administrasi) yang profesional bagi kelompok Sri Amerta Sari dan Karya Santhi di desa Tianyar, (3) meningkatkan jumlah produksi bagi kelompok Sri Amerta Sari dan Karya Santhi di desa Tianyar, (4) meningkatkan desain dan kreativitas hasil kerajinan tempurung kelapa bagi kelompok Sri Amerta Sari dan Karya Santhi di desa Tianyar, dan (4) meningkatkan jumlah permintaan kerajinan tempurung kelapa bagi kelompok Sri Amerta Sari dan Karya Santhi di desa Tianyar.

Manfaat kegiatan ini adalah masyarakat khususnya kelompok Sri Amerta Sari dan Karya Santhi di desa Tianyar memiliki peluang usaha baru yaitu usaha kerajinan kerajinan tempurung kelapa dari tempurung Kelapa yang harapannya berimbas bagi masyarakat disekitarnya, mengetahui dan memahami sistem pembukuan (administrasi) yang profesional, mampu menerapkan IPTEKS dalam meningkatkan jumlah produksi kerajinan tempurung kelapa dari tempurung Kelapa, mengetahui dan memahami desain dan kreativitas hasil kerajinan tempurung kelapa dari dau tempurung Kelapa, dan memiliki pengetahuan tentang tehnik pemasaran melalui sistem online.

Upaya pemecahan yang dapat diusulkan adalah melakukan transfusi IPTEK ke dalam kelompok Karya Santhi dan Sri Amerta Sari, sekaligus melakukan pemberdayaan terhadap semua anggota pada kedua kelompok usaha tersebut tersebut, sehingga dapat melakukan pengelolaan usaha kerajinan tempurung Kelapa secara profesional. Produk teknologi sebagai bentuk solusi yang ditawarkan untuk mengatasi permasalahan kelompok Karya Santhi dan Sri Amerta Sari adalah (1) perancangan dan pembuatan teknologi pemotong tempurung Kelapa dengan berbagai macam ukuran, penghalus tempurung Kelapa agar keajegan dan keindahan 
tempurung Kelapa terjaga dan teknologi pewarna sehingga warna yang dihasilkan bisa bervariasi; (2) Pemberdayaan pengelola kelompok usaha tersebut melalui pelatihan /pendampingan dalam pembuatan kerajinan tempurung Kelapa inovatif dengan tampilan multiwarna yang dilabel dengan aksesori lukisan unik gaya lukisan desa Tianyar; dan 3) perancangan dan pembuatan Web (e-commerce) pemasaran on line kerajinan tempurung Kelapa bagi kedua kelompok usaha tersebut.

Program pelatihan ini akan dilaksanakan di desa Tianyar dengan menyasar kelompok Sri Amerta Sari dan Kelompok Karya Santhi. Tiap kelompok akan diberikan pelatihan sebanyak 20 orang. Sehingga jumlah sassarannya keseluruhan adalah 40 orang. Pelaksanaan P2M ini difokuskan pada pelatihan kerajinan kerajinan tempurung kelapa dari tempurung Kelapa dengan materi pelatihan dasar, pelatihan teknologi, pelatihan desain, pelatihan manajemen, dan pelatihan pelamasaran. Program pelatihan ini hanya melibatkan 2 kelompok yang ada di Desa Tianyar, jadi secara organisasi pelatihan ini akan berkoordinasi dengan kepala Desa Tianyar saja. Namun dalam pelatihan ini akan mengundang ahli desain dan ahli kreasi tempurung Kelapa dari Gianyar.

\section{METODE PELAKSANAAN}

Metode yang digunakan dalam kegiatan ini adalah pelatihan. Tahapantahapan pelatihannya dapat diuraikan sebagai berikut.

\section{(a) Persiapan}

Pada tahap ini melakukan kordinasi dengan pihak desa, dan kelompok Sri Amerta Sari dan Karya Santhi. Kemudian melakukan rekrutmen peserta. Rekrutmen peserta kami lakukan dengan menjalin komunikasi yang baik dengan kedua kelompok. Rekrutmrn peserta tidak memeperhatikan jenis kelamin, artinya kami tidak menentukan proporsi yang pasti untuk jenis kelamin. Baik pria maupun wanita, asal memenuhi kriteria, berpenghasilan rendah, dipandang mau dan mampu mengikuti pelatihan, dan dipandang bersedia untuk menerapkan ilmu yang diperoleh pada pelatihan, akan diikutkan pada pelatihan ini. Dan melakukan penyaringan awal dilakukan oleh kami bersama dengan perangkat desa. Namun kami juga menerapkan syarat tambahan, tidak boleh ada peserta yang suami istri. Ini kami lakukan untuk memberikan kesempatan pada keluarga yang lainnya. Anak-anak kami perkenankan untuk mengikuti kegiatan ini bersama-sama, dengan pertimbangan anak-anak masih sangat produktif mengembangkan dirinya.

\section{(b) Pelaksanaan}

Pelaksanaan pelatihan ini dilakukan dengan model pelatihan ketrampilan berkelanjutan. Pelatihan keterampilan dilakukan sebagai motivasi masyarakat untuk belajar membaca dan menulis. Pembelajaran akan dilakukan seminggu 2 kali. Waktu yang agak senggang itu kami terapkan dengan maksud memberikan kesempatan kepada peserta pelatihan untuk menerapkan ilmu yang diperoleh di rumah masingmasing. Karena peserta pelatihan sebagain besar telah diberikan keterampilan yang berguna untuk dirinya masing-masing. Evaluasi tidak dilakukan dengan menyediakan waktu khusus. Tapi penilaian dilakukan secara berkesinambungan oleh para tutor selama proses pelatihan dilakukan. Penilaian dilakukan dengan memberikan tes keterampilan kepada warga belajar. Penilaian diberikan dalam bentuk angka oleh masing-masing tutor, yang berisikan prestasi dalam bidang teori dan praktek untuk masing-masing kompetensi. Nilai akhir adalah nilai rata-rata dari semua tutor. Lembar nilai akhir, akan diletakkan di belakang STTP, dengan format sebagai berikut. Sertifikat itu diberikan oleh pemerintah provinsi Bali yang bekerja sama dengan pemerintah daerah kabuapten karangasem. Mengingat program ini terbatas waktu selama 114 jam pelajaran, maka untuk meningkatkan kemampaun 
warga belajar tentang teknologi, desain, manajemen, dan pemasaran maka proses kemandirian dan pendampingan. Pendampingan akan dilakukan selama 1 bulan dengan memberikan umpan balik-umpan balik.

\section{(c) Rancangan Evaluasi}

Evaluasi tidak dilakukan dengan menyediakan waktu khusus. Tapi penilaian dilakukan secara berkesinambungan oleh para tutor selama proses pelatihan dilakukan. Penilaian diberikan dalam bentuk angka oleh masing-masing tutor, yang berisikan prestasi dalam bidang teori dan praktek untuk masing-masing kompetensi. Nilai akhir adalah nilai rata-rata dari semua tutor. Lembar nilai akhir, akan diletakkan di belakang STTP, dengan format sebagaiberikut. Nilai diberikan dalam rentang $50 \mathrm{~s} / \mathrm{d} 100$. Peserta berstatus lulus jika memperoleh nilai lebih dari 80. Dari 40 peserta pelatihan yang mengikuti program ini, pelatihan dianggap berhasil jika $95 \%$ peserta dapat menyelesaikan seluruh program pelatihan. Namun harapan penyelenggara, seluruh peserta pelatihan (100\%) agar dapat menyelesaikan program ini.

Evaluasi proses keberhasilan pembelajaran dinilai dari jumlah tagihan dan penilaian yang diberikan tutor diserap oleh pembelajar. Pembelajar dianggap berhasil bila sudah menyerap $80 \%$ materi dalam penyelesaian tugas-tugas belajar dan mampu memanfaatkan pengetahuan yang diperoleh untuk meningkatkan kualitas keterampilan kerajinan tempurung kelapa yang pada akhirnya akan dapat meningkatkan kehidupan perekonomian mereka. Pelatihan ini tidak metargetkan jumlah lulusan yang disalurkan bekerja di perusahaan keterampilan. Ini karena mengingat di sekitar lokasi tidak terdapat lokasi perusahaan keterampilan keset tersebut. Selain itu menimbang para lulusan akan memiliki kemampuan permodalan, teknis, dan pemasaran yang memadai untuk berusaha mandiri, maka lulusan pelatihan lebih diarahkan untuk membuka usaha sendiri.

\section{HASIL DAN PEMBAHASAN Hasil Yang Dicapai 1) Gambaran Umum}

Pelaksanaan kegiatan Pengabdian kepada Masyarakat ini dilaksanakan pada bulan Juni - September 2015 yang telah dilaksanakan dengan penggunaan dana $70 \%$ program yaitu: pendidikan dan pelatihan tempurung kelapa. Diklat pengelolaan kawasan, dan pelatihan manajemen produksi dan kewirausahaan. Hal yang masih berlangsung sampai saat ini adalah pendampingan kelompok dalam pengurusan ijin usaha perdagangan (SIUP) dengan karakteristik usaha bersama kelompok (UBK).

Pada tahap awal pelaksanaan program dilaksanakan kegiatan berupa perancangan, sosialisasi dan koordinasi dengan peserta. Perancangan disain dan kegiatan diklat dilaksanakan bersama tim pengusul didasari oleh analisi situasi yang dibuat berdasarkan permasalahan yang dihadapi oleh kelompok Sri Amerta Sari dan Kelompok Karya Santhi. Perancangan ini dilaksanakan pada akhir bulan Juni dan pertengahan Agustus 2015 yang juga melibatkan peran serta aktif peserta program pengabdian kepada masyarakat untuk membuat skala prioritas program yang dilaksanakan. Perencanaan ini berjalan dengan sangat baik berkat peranan aktif tim pelaksana dan peserta yang menjadi mitra program.

Persiapan tutor dan instruktur dilaksanakan pada awal kegiatan untuk mematangkan kembali program - program yang akan dilaksanakan kepada mitra, sehingga terjadi sinergi yang baik dalam kegiatan ini. Persiapan tutor dan instruktur ini meliputi: sistem pembukuan (administrasi) yang profesional, desain dan kreativitas hasil kerajinan tempurung kelapa, dan pelatihan manajemen produksi dan kewirausahaan, serta pengurusan SIUP untuk usaha baru. Persiapan yang dilaksanakan berikutnya berupa persiapan alat dan bahan yang dilaksanakan dengan pembelian: peralatan pelatihan alat penunjang usaha produksi, bahan kelengkapan pelatihan kerajinan tempurung kelapa, pelatihan 
manajemen produksi dan kewirausahaan, dan bahan pelatihan SIUP yang dijadwalkan pada akhir program.

Dalam rangka penyamaan persepsi dan waktu pelaksanaan kegiatan pengabdian kepada masyarakat di kelompok Sri Amerta Sari dan Kelompok Karya Santhi, maka dilaksanakan kegiatan sosialisasi dan koordinasi dengan peserta. Hal ini dilaksanakan untuk mendapatkan kesepakatan waktu dalam pelaksanaan program, sangat disyukuri peserta kegiatan sangat antusias dalam menerima sosialisasi program sehingga tidak ada halangan yang berarti dalam pelaksanaan kegiatan ini.

\section{2) Pendidikan dan Pelatihan Perancangan Alat Usaha}

Pada dasarnya pendidikan dan perancangan alat penunjang usaha kerajinan tempurung kelapa dan penataan los diberikan oleh instruktur tamu yang berprofesi sebagai undagi di Tianyar yakni I Made Suastawa kepada kelompok Sri Amerta Sari dan Kelompok Karya Santhi bersifat sharing informasi dan teknologi karena apa yang sudah dilaksanakan beliau selama ini sudah sangat bagus tetapi terkadang masih menggunakan peralatan manual. Semangat dan kreatifitas dari Bapak Made membuahkan banyak ide-ide inovatif baru dalam pelatihan ini, sehingga diharapkan di masa mendatang usaha kerajinan tempurung kelapa yang akan dikelola beliau oleh kelompok Sri Amerta Sari dan Kelompok Karya Santhi semakin berkembang.

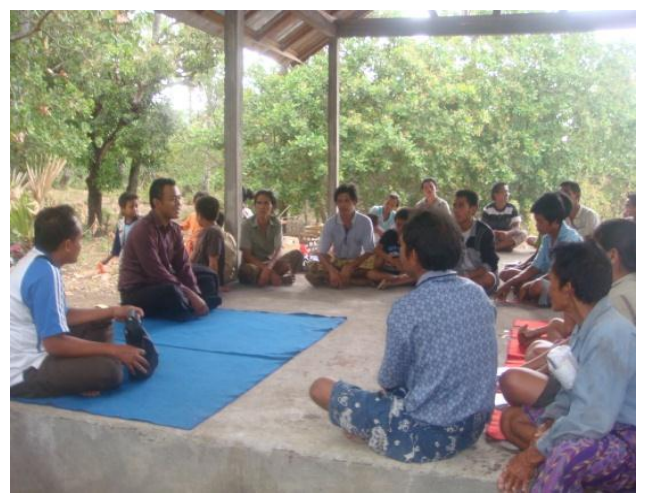

Pendidikan dan pelatihan produksi peralatan usaha kerajinan tempurung kelapa yag dilaksanakan pada saat ini masih menitik beratkan pada produksi bahan untuk menunjang perkakas usaha kerajinan tempurung kelapa yang akan dibuka, dalam artian bahan-bahan kelengkapan peralatan diolah dan dikerjakan sendiri sebagai bentuk kreatifitas pemberdayaan kelompok. Meskipun dalam perjalanan program dicoba dilakukan pengolahan bahan peralatan perkakas usaha kerajinan tempurung kelapa ke depannya diharapkan dapat lebih efesien kalau anggota kelompok dapat diberdayakan dalam pengerjaannya.

Pendidikan dan pelatihan perancangan alat perkakas usaha kerajinan tempurung kelapa ini dilaksanakan pada tanggal 26 Juni sampai dengan 7 Agustus 2015, bertempat di kediaman koordinator Kelompok Sri Amerta Sari dan Kelompok Karya Santhi, Banjar Dinas Tunassari, Desa Tianyar, Kecamatan Kubu, Kabupaten Karangasem, Bali. Pendidikan dan pelatihan dilaksanakan melalui metode praktek langsung pengolahan bahan baku tempurung kelapa, dan sebagainya sehingga siap menjadi bahan dasar produk kreatif yang selanjutnya digunakan pada usaha kelompok.

Dalam pelaksanaan diklat ini tidak ditemukan kendala yang berarti karena respon yang sangat bagus dari kelompok Sri Amerta Sari dan Kelompok Karya Santhi dalam mengikuti pelaksanaan kegiatan ini.

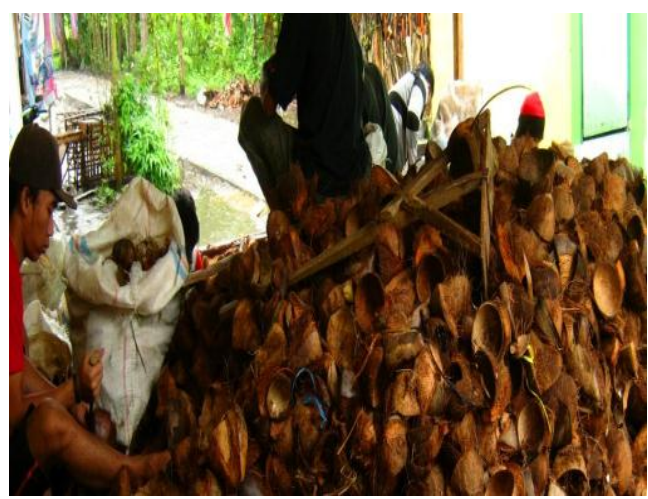




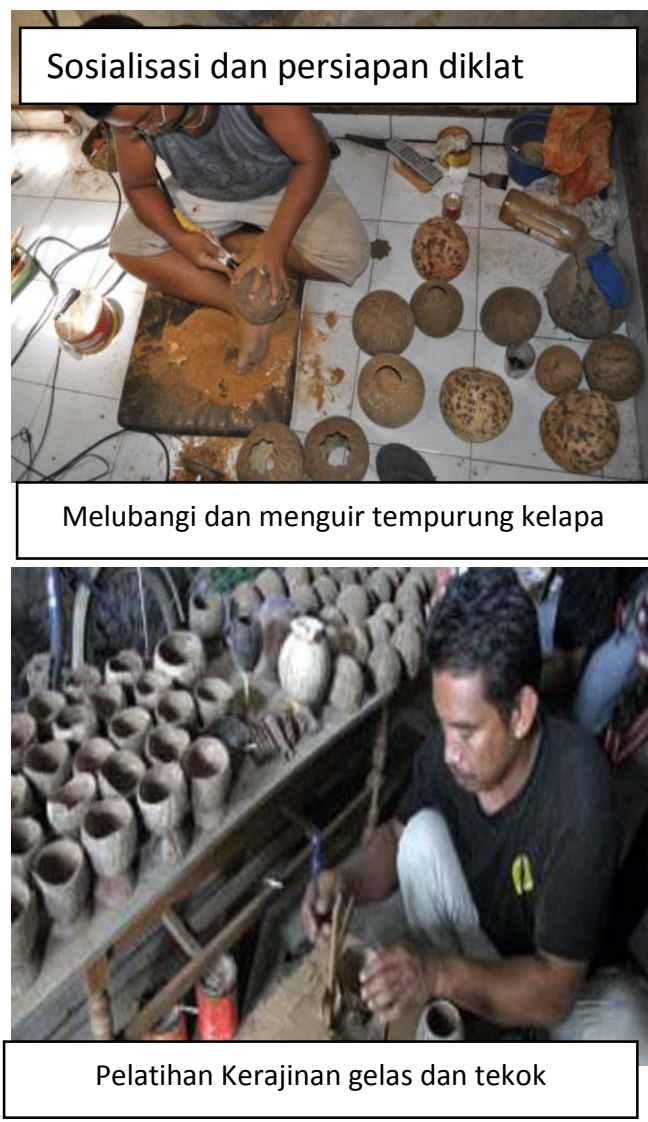

\section{3) Diklat Manajemen Produksi dan} Kewirausahaan

Kegiatan ini dilaksanakan pada tanggal 19-20 Agustus oleh instruktur tamu dari pengusaha pasar oleh-oleh Bali di Kuta yaitu bapak Komang Sukayasa Yang melakukan pendampingan tentang manajemen usaha dengan pengelolaan usaha kreatif mandiri secara berkelompok oleh kelompok Sri Amerta Sari dan

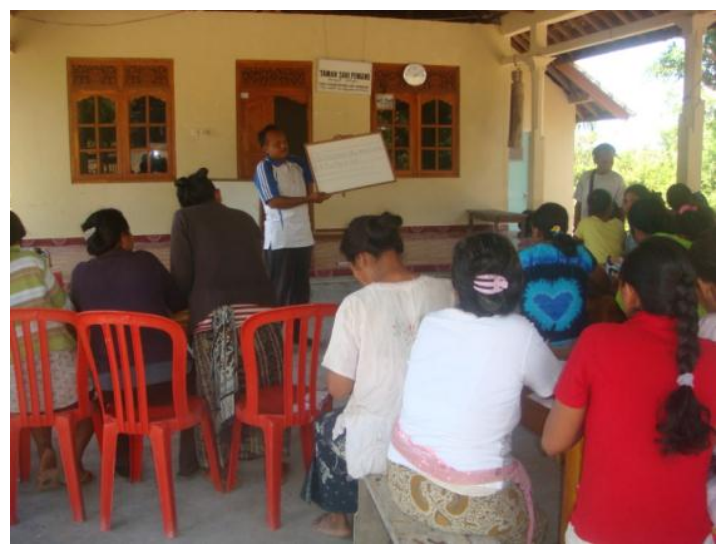

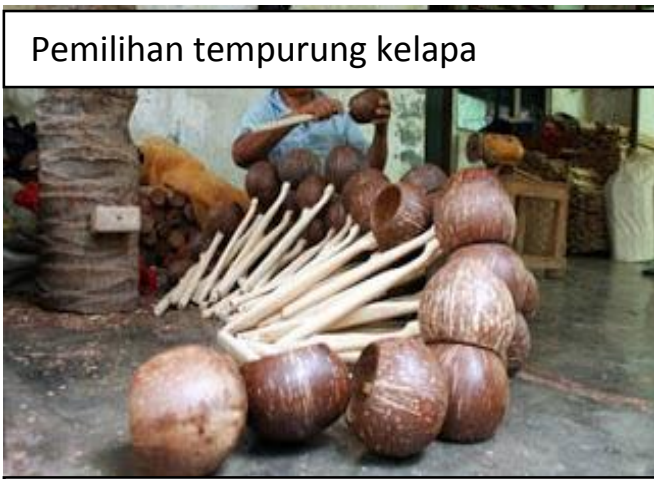

Pelatihan Kerajinan sendok besar

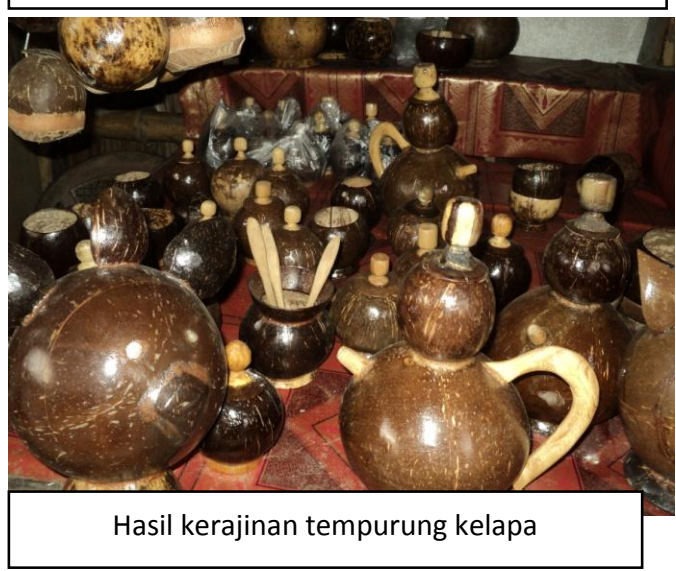

Kelompok Karya Santhi sekaligus membuka peluang baru berupa usaha kerajinan tempurung kelapa yang merupakan bentuk UBK rintisan. Respon masyarakat sangat positif sekali mengingat selain materi penekanan pada usaha tempurng kelapa yang digalakkan juga terdapat pendampingan manajemen pembukuan sederhana untuk menunjang administrasi kelompok.

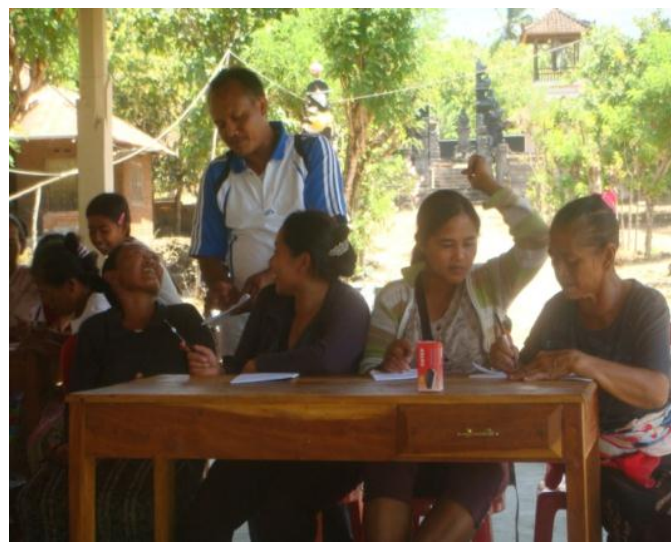

Pelatihan manajemen dan administrasi kelompok 


\section{4) Rancangan Pengurusan SIUP UBK}

Sesuai hasil kesepakatan dengan anggota kelompok pendampingan selanjutnya yang akan dilaksanakan oleh instruktur pendamping Dr. Desak Putu Parmiti, MS adalah pengurusan surat ijin usaha perdagangan (SIUP) yang dalam hal ini akan digunakan nama kelompok yang sudah disepakati sebelumnya yaitu Usaha kerajinan tempurung kelapa kelompok Sri Amerta Sari dan Kelompok Karya Santhi, supaya dapat berkekuatan hukum akan diurus pendaftarannya secara administratif setelah usaha kerajinan tempurung kelapa berjalan dan sekaligus menjadi identitas bagi kelompok. Hal ini dilakukan untuk melindungi produk-produk kreatif yang akan dihasilkan oleh kelompok dikemudian hari. Kemudian tahap selanjutnya adalah pemandirian dan pendampingan selama masyarakat membuka usaha mandiri. Pemandirian dilakukan dengan memberikan materi motivasi dan menjalin kerjasama untuk mencari modal kerja.

\section{Pembahasan}

Setelah diberikan pelatihan oleh tim pelaksana dari Undiksha Singaraja, masyarakat Desa Tianyar Kecamatan Kubu dapat memahami dengan jelas materi pelatihan kerajinan tempurung kelapa yang semula kurang terampil menjadi lebh terampil dan dapat dipraktekannya menjadi beragam jenis kerajinan dengan desain yang unik dan menarik. Sehingga tujuan dari pengabdian ini dapat tercapai dengan dengan baik yaitu mampu meningkatkan pengetahuan dan wawasan masyarakat tentang pengolahan tempurung kelapa menjadi kerajinan yang memiliki nilai jual tinggi.

Keunggulan yang dapat dilihat dali pelaksanaan program, bahwa berdasarkan hasil evaluasi tidak lanjut juga terekam, beberapa manfaat praktis yang diperoleh oleh masyarakat, yaitu: (1) mereka mendapatkan informasi yang jelas dan utuh mengenai hakekat pemberdayaan masyarakat dari segi pengetahuan dan keterampilan, bermakna untuk penciptaan lapangan pekerjaan baru yang sifatnya inovatif dari kerajinan tempurung kelapa; (2) masyarakat yang menjadi peserta pelatihan memperoleh gambaran yang jelas mengenai langkah pengembangan iklim usaha dengan memanfaatkan komoditas lokal; peserta pelatihan juga mendapatkan gambaran yang jelas dan utuh tentang manfaat hasil komoditi lokal apabila dikelola dengan baik akan mendatangkan nilai finansial.

\section{Kendala dan Tindak Lanjut yang harus Dilakukan}

Kendala pelaksanaan program adalah sulitnya meminid waktu untuk pencapaian kesepakatan pelaksanaan kegiatan, karena umumnya peserta latihan terbentur dengan rutinitas pekerjaan harian yang menunjang perekonomian keluarga, maupun pelaksanaan kegiatan ritual adat-istiadat yang lumayan padat di Desa Tianyar Kecamatan Kubu dalam kaitannya dengan paruman desa adat untuk penyelenggaraan ritual keagamaan sebagaimana layaknya masyarakat Hindu Bali pada umumnya. Jadi, untuk bisa mengkoordinir warga perlu koordinasi intensif dengan pihak msyarakat. Berkaitan dengan pengkondisian peserta program, walaupun dijumpai kendala masalah waktu selama tim pelaksana program mampu mengatasinya dengan melakukan koordinasi secara intensif dengan Kepala Desa Tianyar dan masyarakat yang ikut peatihan. Program ini masih berlangsung dan masih banyak terdapat kekuarangan-kekurangan yang ada dalam pengabdian ini.

\section{PENUTUP}

Kesimpulan yang dapat diperoleh dari pelaksanaan program pengabdian kepada masyarakat ini adalah:

1. Tingkat partisipasi yang tinggi dari mitra program pengabdian kepada masyarakat memberikan dampak positif bagi pelaksanaan program, terlihat dari kehadiran peserta yang tanpa ijin, dan dukungan dari kepala desa.

2. Hasil pelatihan menunjukkan bahwa dari 30 orang yang ikut pelatihan 25 orang $(83,33 \%)$ masuk dalam kategori sangat mengetahui dan terampil dalam pembuatan kerajinan tempurung 
kelapa, 2 orang $(2,66)$ termasuk dalam kategori kategori mengetahui dan terampil dalam pembuatan kerajinan tempurung kelapa, dan 5 orang $(16,66)$ termasuk dalam kategori cukup mengetahui dan terampil pembuatan kerajinan tempurung kelapa

3. Hasil pelatihan menunjukkan bahwa dari 30 orang yang ikut pelatihan 20 orang $(66,67 \%)$ masuk dalam kategori sangat mengetahui dan terampil dalam mengkreasikan kerajinan tempurung kelapa, $5(16,66)$ orang termasuk dalam kategori kategori mengetahui dan terampil dalam mengkreasikan kerajinan tempurung kelapa, dan 5 orang $(16,66)$ termasuk dalam kategori cukup mengetahui dan terampil dalam kerajinan tempurung kelapa.

4. Kendala pelaksanaan program adalah sulitnya meminid waktu untuk pencapaian kesepakatan pelaksanaan kegiatan, karena umumnya peserta latihan terbentur dengan rutinitas pekerjaan harian yang menunjang perekonomian keluarga, maupun pelaksanaan kegiatan ritual adat-istiadat yang lumayan padat di banjar tunassari desa Tianyar dalam kaitannya dengan paruman desa adat untuk penyelenggaraan ritual keagamaan sebagaimana layaknya masyarakat Hindu Bali pada umumnya.

Bagi pihak terkait, yang dalam hal ini Pemerintah Desa Tianyar, diharapkan dapat memberikan dukungan kemudahan kebijakan dan berbagi pengalaman dari segi wawasan pengetahuan yang ditransfer ke masyarakat guna menyukseskan rintisan program usaha industri rumah tangga yang telah digagas secara kolektif tersebut.
DAFTAR PUSTAKA

Dasman, Raymon. 1980. Prinsip Ekologi Untuk Pembangunan, Terjemahan Idjah Soemarwoto. Jakarta: Gramedia.

Gerungan. 1988. Psikologi Sosial. Bandung: Unesco.

Karama dan Abdurrachman. 1995. Kebijakan Nasional dalam Penanganan Lahan Kritis di Indonesia. Yogyakarta: BPTP Prosiding Seminar Rekayasa Teknologi Konservasi.

Kurana. 2008. Sukses Mengembangkan Wirausaha. Jakarta: Grsindo.

Kurniasih Dian. 2006. Pengaruh Daya Dukung Lahan dan Faktor Sosial Ekonomi terhadap Perilaku Petani dalam Konservasi Lahan Pertanian di Kabupaten Kulon Progo. Yogyakarta: Program Studi Ekonomi Pertanian, Jurusan IImu-IImu Pertanian, UGM.

Muhadjir, N. 1993. Kepemimpinan Adopsi Inovasi untuk Pengembangan Masyarakat. Yogyakarta: Rake Press.

Negara Republik Indonesia. UndangUndang Nomor 5 Tahun 1999 tentang Larangan Praktek Monopoli dan Persaingan Usaha Tidak Sehat. Lembaran Negara Nomor 33, TLN RI Nomor 3817.

Pemerintah Kabupaten Karangasem. Data Statistik Desa Tianyar Tahun 2011. Karangasem: Tianyar.

Suhardjo. 1988. Peranan Kelembagaan dalam Hubungannya dengan Komersialisasi Usahatani dan Distribusi Pendapatan Wilayah Kabupaten Banjar Negara Jawa Tengah. Disertasi (tidak dipublikasikan). Yogyakarta: UGM.

Soemarwoto, Otto. 2001. Ekologi, Lingkungan Hidup, dan Pembangunan. Jakarta: Penerbit Djambatan.

Susanto, P.Astrid. 1983. Pengantar Sosiologi dan Perubahan Sosial. Jakarta: Bina Cipta. 